\title{
Purification and characterization of lipase produced by indigenously isolated bacteria
}

\author{
Muhammad Aqeel Sultan ${ }^{1}$, Muhammad Javaid Asad ${ }^{1 *}$, Raja Tahir \\ Mahmood $^{2}$, Majid Mahmood ${ }^{3}$, Sidrah Nazir ${ }^{1}$ and Muhammad Basir \\ Shah $^{4}$ \\ 1. University Institute of Biochemistry and Biotechnology (UIBB), PMAS-Arid Agriculture University \\ Rawalpindi-Pakistan \\ 2. Department of Biotechnology, Mirpur University of Science and Technology (MUST), Mirpur AJK-Pakistan \\ 3. Department of Zoology, University of Poonch, Rawalakot AJK-Pakistan \\ 4. Department of Plant Breeding \& Genetics, Balochistan Agriculture College Quetta-Pakistan \\ *Corresponding author's email: javaidasad@uaar.edu.pk
}

Citation

Muhammad Aqeel Sultan, Muhammad Javaid Asad, Raja Tahir Mahmood, Majid Mahmood, Sidrah Nazir and Muhammad Basir Shah. Purification and characterization of lipase produced by indigenously isolated bacteria. Pure and Applied Biology. Vol. 9, Issue 4, pp2521-2528. http://dx.doi.org/10.19045/bspab.2020.90268

\begin{tabular}{|c|c|c|c|}
\hline Received: 16/04/2020 & Revised: 01/07/2020 & Accepted: 09/07/2020 & Online First: 06/08/2020 \\
\hline
\end{tabular}

\section{Abstract}

Bacteria including Bacillus species often produce extracellular enzymes to degrade substances such as proteins, lipids, and starch. Glycerol and long-chain fatty acids are hydrolyzed by lipases (triacylglycerol acylhydrolases, EC 3.1.1.3) to generate esters. Bacterial strains were isolated from rotten fruits and vegetables and cultured at 20 to $50{ }^{\circ} \mathrm{C}$ with different types of substrates (Olive oil, Mustard oil and Tributryne). Extracellular enzymes produces from bacteria with different physical parameter and also using different substrates. Only two strains, strain 1 and strain 2 show results when provided substrate Olive oil and Mustard oil at $\mathrm{pH} 7$ and at temperature $30^{\circ} \mathrm{C}$ but Tributryne show result at $\mathrm{pH} 9$ and at temperature $40^{\circ} \mathrm{C}$. Addition of maltose and fructose increased the lipase activity to $28.53 \mathrm{U} / \mathrm{mL}$ and $30.17 \mathrm{U} / \mathrm{mL}$ respectively. The activity enhance to $50.83 \mathrm{U} / \mathrm{mL}$ by the addition of yeast extract as nitrogen source. Addition of $60 \%$ ammonium sulfate results in maximum precipitation with activity $59.46 \mathrm{U} / \mathrm{mL}$. The results concluded that isolated bacterial strains are good producer of lipase enzyme. The purified enzyme could be a good candidate for various industrial applications.

Keywords: Ammonium sulfate precipitation; Bacillus species; Lipase activity; Rotten fruits; Tributryne agar Plate

\section{Introduction}

The earlier cultures can be used to check the enzyme-mediated processes. Now a days, around 4000 enzymes were discovered from which 200 are used in various industries. The source of most of the manufacturing enzymes are different bacterial species. Overall, few million dollars trades of enzymes per annum till 1960, but later enormously developed taken placed in market. For the convenience of better development of biochemistry, many processes like fermentation recovery or producing many number of enzymes at reasonable cost. Similarly, the improvements in methods of using enzymes on request have significantly increasing. Besides, Enzymes can catalyze due to many diverse revolutions, in market enzymes number continues to proliferate. World 
enzyme demand is fulfilled by 400 unimportant sellers and 12 main manufacturers. World supply of $60 \%$ enzymes manufactured is taken placed by Europe. By hydrolytic action of lipase, free fatty acids are produced enzyme on triacylglycerol. Lipolytic enzymes that carry out oil water interface and are soluble in water [1]. Many type of reactions like Trans esterification; acidolysis, aminolysis, hydrolysis and esterification all are occurred by these enzymes. These enzymes are extensively present in animals, plants and microorganisms. Microorganisms are the most fundamental and commercial source of getting these enzymes lipases. Microbial lipases are the most steady form of lipases according to. Flooded, fine disturbed and situation aerated $[2,3]$.

Report have also been given that lipases are produced both by synthetic and nonsynthetic substrates. In 1997, Benjamin and Panday studied that maximum production of lipase is done by Candida rugose due to organisms containing on cultured medium urea (1\%), maltose $(5 \%)$, peptone $(3 \%)$, and olive oil (10\%). Submerged fermentation, with complex culture media that comprising compounds like corn steep liquor, egg yolk, and yeast extract, and soy meal produces fungal lipases [4]. Lipases can be easily produced and secreted by pathogens and highly selective, so it makes best enzymes, their crystal structure is well illustrated [5] the usage of lipases involves generation of cosmetics, production of biopolymers, utilize an herbicide and as a best solvent [6]. The main objective of the current study was the isolation of lipase producing bacterial strains from the rotten fruits. Improving lipase production and its partial purification.

\section{Materials and methods}

\section{Sample collection}

Rotten fruits and vegetables were collected from the markets of Rawalpindi and Islamabad during summer season for separating bacteria producing extracellular enzyme [7]. The samples were properly labeled and preserved.

\section{Culturing of bacteria}

Normal saline solution $(0.9 \% \mathrm{NaCl}$ in distilled water) was used to dissolve the rotten parts of the samples and spread it on a medium comprising $2 \%$ agar, $1 \%$ yeast extract, $1 \%$ Peptone and $0.5 \%$ sodium chloride (Yeast Extract Peptone (YEP) medium) and then grown at temperature 50$70^{\circ} \mathrm{C}[8]$.

\section{Screening of bacteria}

When the bacteria cultured, then they undergoes screening on Tributyrin Agar Plates (TBA) comprising 5g beef extract, $3 \mathrm{~g}$ tributyrin, per liter of peptone, $10 \mathrm{~mL}$ and agar-agar, $20 \mathrm{~g}$ followed by incubation for 24-48 hrs at $37{ }^{\circ} \mathrm{C}$ for screening of lipase producing microorganisms.

\section{Innoculation of bacteria}

For the preparation of inoculums, a loopful of cells from fresh slant was transferred into conical flask containing minimal media without agar $\left(\mathrm{NH}_{4} \mathrm{Cl} 2.0 \mathrm{~g}, \mathrm{NaCl} 5.0 \mathrm{~g}\right.$, $\mathrm{Na}_{2} \mathrm{HPO}_{4} 6.0 \mathrm{~g}, \mathrm{KH}_{2} \mathrm{PO}_{4} 3.0 \mathrm{~g}, \mathrm{MgSO}_{4} 0.1$ $\mathrm{g}$ in $1 \mathrm{~L}$ of distilled water) and placed at 37 ${ }^{\circ} \mathrm{C}$ in shaking incubator at $180 \mathrm{rpm}$ for $24 \mathrm{~h}$ [9].

\section{Lipase assay}

Lipase assay Lipase activity was assayed quantitatively by using para-nitro phenyl acetate (pNPA) as the substrate. One milliliter of methanol containing $0.2 \mathrm{mg}$ pNPA and sixty milliliter of acetonitrile was mixed with $50 \mathrm{mM}$ phosphate buffer containing $0.087 \mathrm{~g}$ of $\mathrm{K}_{2} \mathrm{H}_{2} \mathrm{PO}_{4} \mathrm{mg}$ and 0.06 $\mathrm{mg} \mathrm{K}_{2} \mathrm{H}_{2} \mathrm{PO}_{4}$. A total volume of $0.9 \mathrm{ml}$ freshly prepared substrate solution in the ratio of 1:4:95 Acetonitrile $(1 \mathrm{ml})$ with PNPA, Ethanol (4 ml) and Phosphate buffer $(95 \mathrm{ml})$ was mixed with $0.3 \mathrm{ml}$ enzyme solution. After $15 \mathrm{~min}$ incubation at $60^{\circ} \mathrm{C}$ in water bath, absorbance at $405 \mathrm{~nm}$ was measured against the blank. The amount of enzyme that liberates $1 \mu \mathrm{g}$ pNPA per minute is considered as one unit. Lipase activity was detected by measuring the hydrolysis of p-nitrophenyl esters [10].

\section{Effect of pH on Lipase activity}

To check the effect of $\mathrm{pH}$ on lipase, activity was performed at $37{ }^{\circ} \mathrm{C}$ at $\mathrm{pH}$ ranging from 5 to 9 and using three different substrates. 
$\mathrm{pH}$ was maintained by using Tris- $\mathrm{HCl}$ buffer having $\mathrm{pH} 7.0$ to 9.0 , acetate buffer $\mathrm{pH} 5.0$ to 6.0, and phosphate buffer $\mathrm{pH} 6.0$ to 8.0 .

\section{Effect of temperature on Lipase activity}

Temperature effect the enzyme by increasing or decreasing its stability and its activity. Adjustment of temperature at its optimum point, results into higher and efficient production of enzymes. Both isolated strains were incubated from $20{ }^{0} \mathrm{C}$ to $50{ }^{\circ} \mathrm{C}$, to find the effect of temperature on lipase.

\section{Effect of carbon source}

To check and enhance the lipase production, various readily available carbon sources other than media were used. Their impact on lipase activity was check through enzyme assay as described earlier. The carbon sources used were glucose, fructose, lactose, manifold, maltose, sucrose and starch [11].

\section{Effect of nitrogen source}

Various nitrogen sources were also added during the incubation of bacteria with media, to find their effect on bacterial growth and on lipase activity. Peptone, tryptone, beef extract, yeast extract, ammonium sulphate, ammonium chloride and ammonium nitrate were used [12].

\section{Ammonium sulphate purification}

Ammonium sulfate is a salt with high ionic strength, causes the precipitation of proteins at higher concentrations. For the partial purification of lipase, various concentrations of ammonium sulfate were added including $1 \mathrm{~g}, 1.5 \mathrm{~g}, 2 \mathrm{~g} 2.5 \mathrm{~g} 3 \mathrm{~g}$ and $3.5 \mathrm{~g}$ in $5 \mathrm{~mL}$ of crude extract produced under optimum conditions [13]. These concentrations gave final concentration of ammonium sulfate to 20, 30, 40, 50, 60 and $70 \%$ in the crude extract. Each of the text tubes were placed at $4{ }^{\circ} \mathrm{C}$ for overnight and next day were centrifuged at $10000 \mathrm{rpm}$ for 10 minutes. Lipase activity assay was performed for each concentration of ammonium sulfate [14]. Both supernatant and pellete were subjected to lipase assay, after suspended the pellete in phosphate buffer.

\section{Results and discussion \\ Isolation of bacteria from rotten fruits and vegetables}

High amount of bacteria is present in contaminated sites with organic waste revealed by microbiological analysis of rotten fruits and vegetables. These types of samples were diluted in normal saline solution $(0.9 \% \mathrm{NaCl}$ in distilled water) and then plated in Nutrient agar to check the total viable count.

\section{Screening of Lipolytic bacterial strains}

For the study two potential isolates were selected, forming clear zone. The isolates were further cultured in Tri-butyrin broth at $\mathrm{pH}(5,6,7,8 \& 9)$ for the production of lipase for two days. It was reported by Pogaku et al. [15] that two days for Staphylococcus spp is better time for production of extracellular enzymes.

\section{Effect of Temperature on Lipase}

The results obtained during this research shows that lipase produce by isolated bacterial strains have good activity from 30 ${ }^{0} \mathrm{C}$ to $40{ }^{0} \mathrm{C}$ with varying substrate. The maximum activity was obtained at $30{ }^{\circ} \mathrm{C}$ with olive oil and Mustard oil as substrates and $40{ }^{\circ} \mathrm{C}$ with trybutryne as a substrate. These finding suggests the affinity of lipase vary towards different substrates with varying activities (Fig. 1-3).

Apergillus oryzae gives maximum lipase at $40^{\circ} \mathrm{C}$ using olive oil as a substrate and by using 4Nitropheyl palmitate as substrate its thesis completed and was reported by Toida et al. [16]. The maximum enzyme activity was taken by Penicillium simplicissimum at $60^{\circ} \mathrm{C}$ reported by Sztejer et al. [17]. It was reported in later study by $\mathrm{Kim}$ et al. [18] that the lipase obtained from hemophilic strain was the majority vigorous at $40^{\circ} \mathrm{C}$ taken by Bacillus stearothermophilus.C10C6 P-nitro phenyl esters used as substrates. 


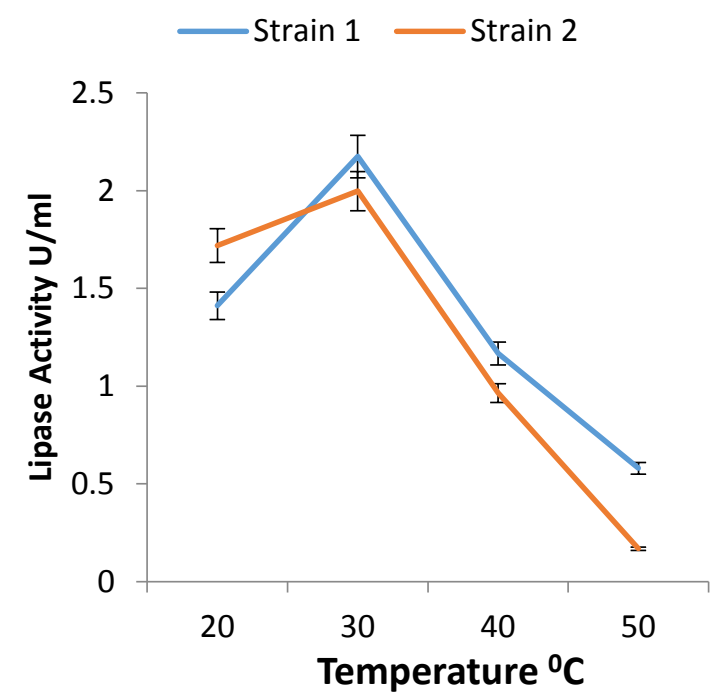

Figure 1. Temperature range of strain 1 and strain 2 with olive oil use as substrate

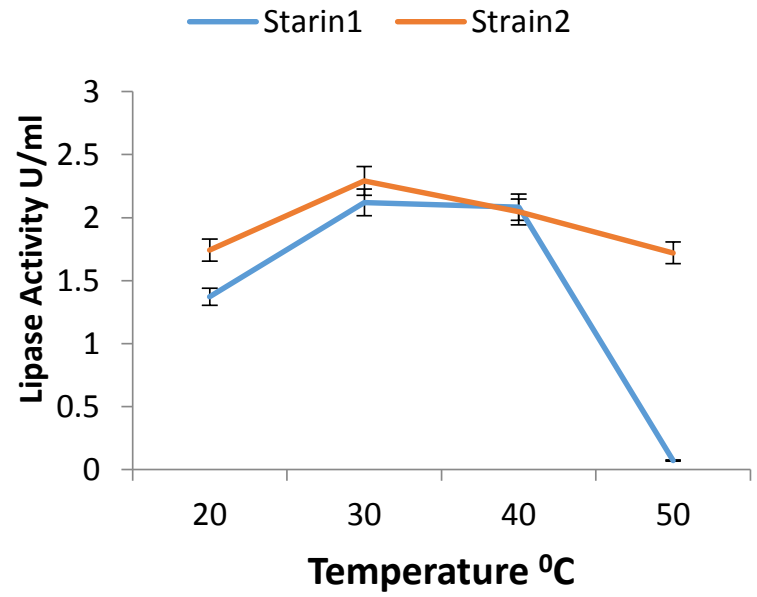

Figure 2. Temperature range of strain 1 and strain 2 with Mustard oil use as substrate

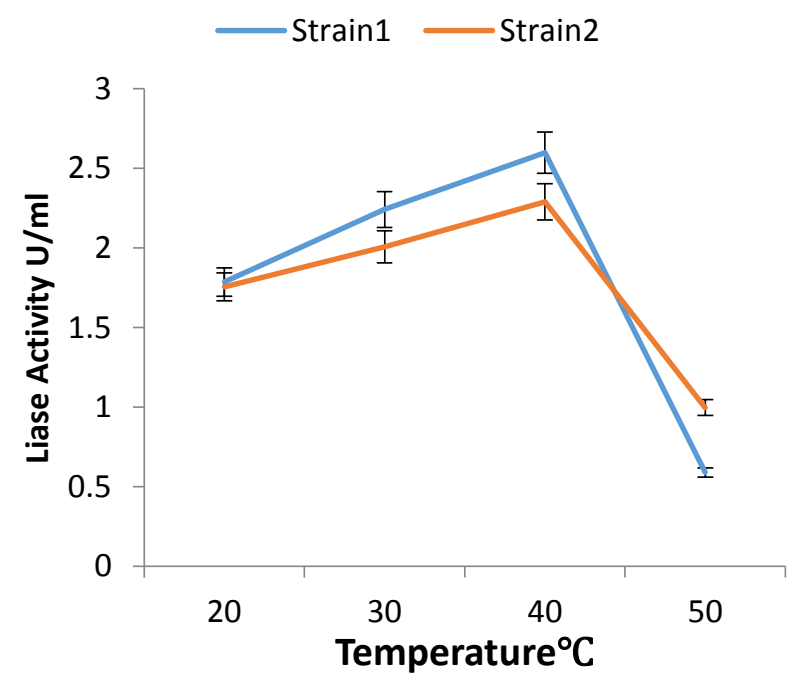

Figure 3. Temperature range of strain 1 and strain 2 with Trybutryne use as substrate 


\section{Effect of pH on lipase}

The lipase enzyme from the both strains having very good catalytic activity at neutral $\mathrm{pH}$ with different substrates. Lipase from both strain has maximum activity at pH 7 with mustard oil and olive oil as substrates. Only strain 2 has higher activity in alkaline range with trybutryne as a substrate (Fig. 4-6).

Motai et al. [19] studied that the Torulopsis $\mathrm{pH}$ is 6.5 by using different $\mathrm{pH}$ buffer at (PNP) ester and temperature is $40^{\circ} \mathrm{C}$ for optimum enzymes. On the other hand, Sztajer et al. [17] studied that Penicillium Simplicissimum, best possible $\mathrm{pH}$ is 5 . Lee et al. [20] reported that best possible $\mathrm{pH}$ for lipase from $35 \mathrm{~K}$ strain is 8.0-9.0. For Pseudomonas putida, according to Lee et al. [20] study a pH 6.5 P -Nitro phenyl.

\section{Effect of carbon source}

Some carbohydrates were added in the culture media to study their effect on lipase production and activity. Lipase activity increases by maltose and fructose, $28.53 \mathrm{U} /$ $\mathrm{mL}$ and $30.17 \mathrm{U} / \mathrm{ml}$ respectively (Fig. 7).

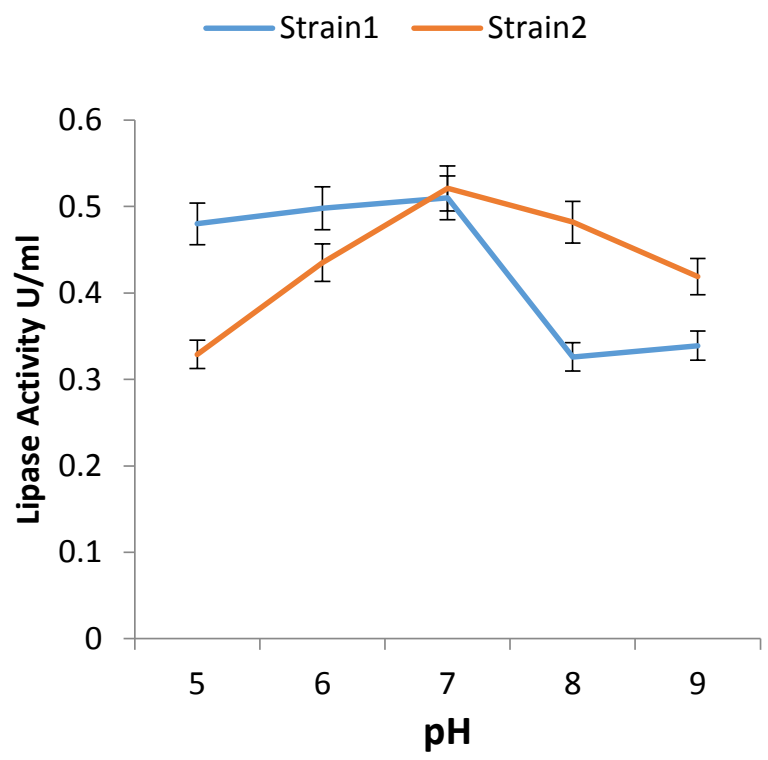

Lipase main source was carbon observed by Lotti et al. [21].

\section{Effect of Nitrogen source}

The results shows that yeast extract and peptone are the better nitrogen sources for bacteria. These enhance the division of bacterial cell and cause increases in the production of lipase. There was maximum activity $(50.83 \mathrm{IU} / \mathrm{mL})$ by the addition of yeast extract as additional nitrogen source (Fig. 8). Many others chemicals like ammonium chloride and peptone also effected the production of enzyme. On the other hand, lactose from Cryptococcus $\mathrm{sp}$ increase lipase synthesis reported by Kamini et al. [22].

\section{Partial purification}

Ammonium sulfate causes the precipitation of lipase produced by the isolated bacterial strains. Its concentration increases in pellete and in the presence of $60 \%$ ammonium sulfate maximum precipitation was achieved with increased activity (59.46/IU/ml/min) as shown in (Fig. 9).

Figure 4. pH range of strain 1 and strain 2 with Olive Oil use as substrate 


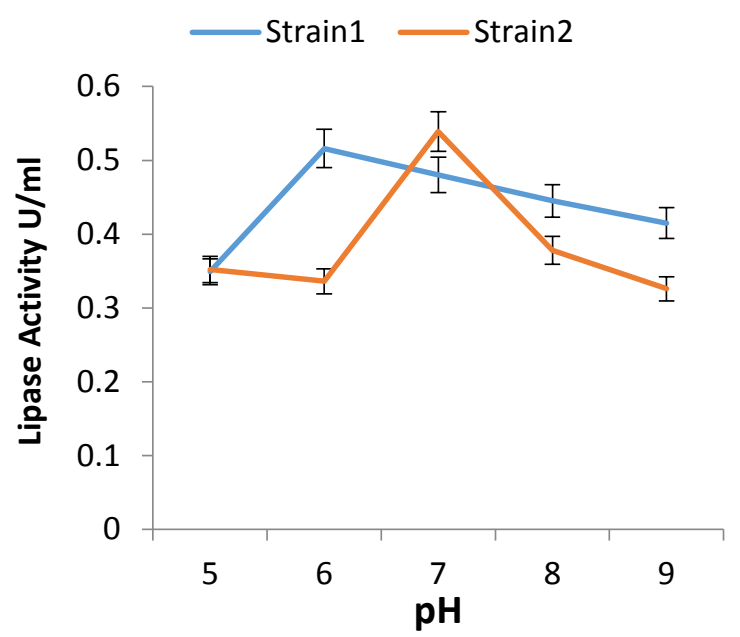

Figure 5. pH range of strain 1 and strain 2 with Mustard oil use as substrate

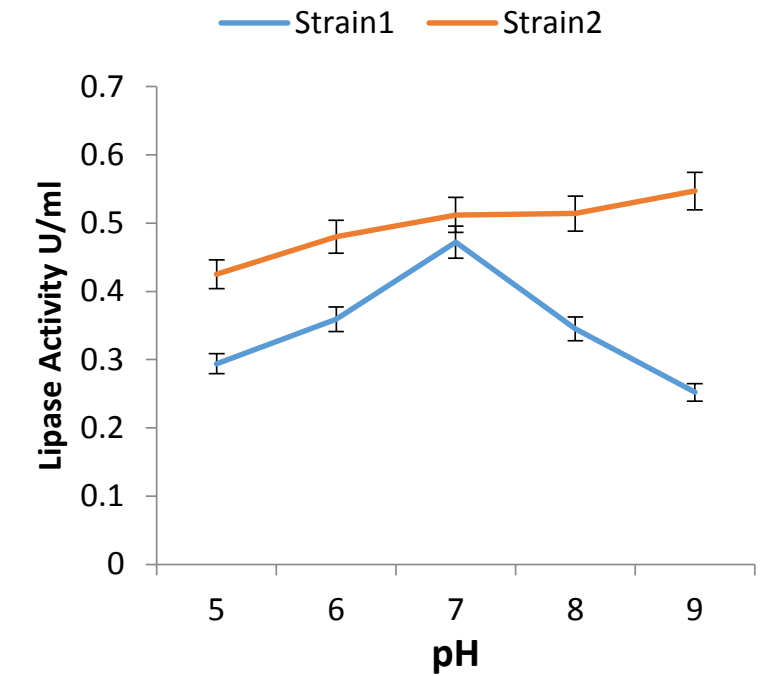

Figure 6. pH range of strain 1 and strain 2 with Trybutryne use as substrate

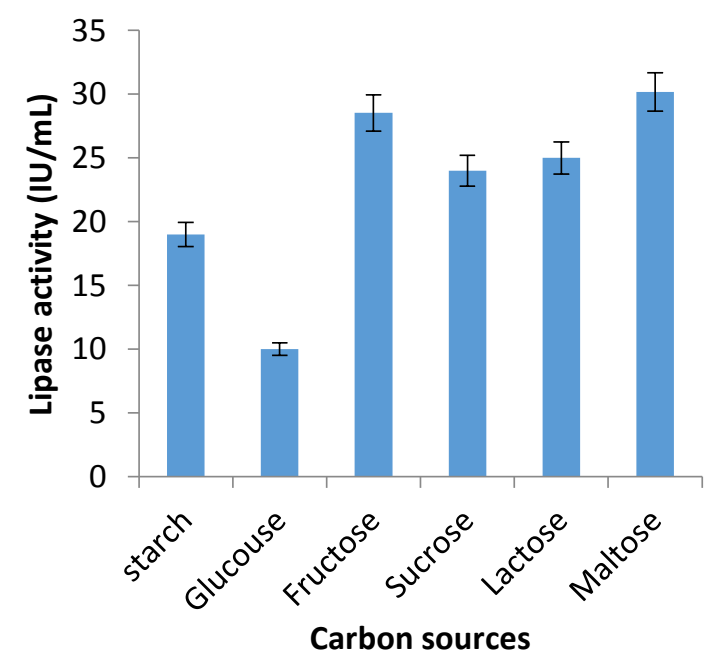

Figure 7. Effect of carbon sources on Enzyme production 


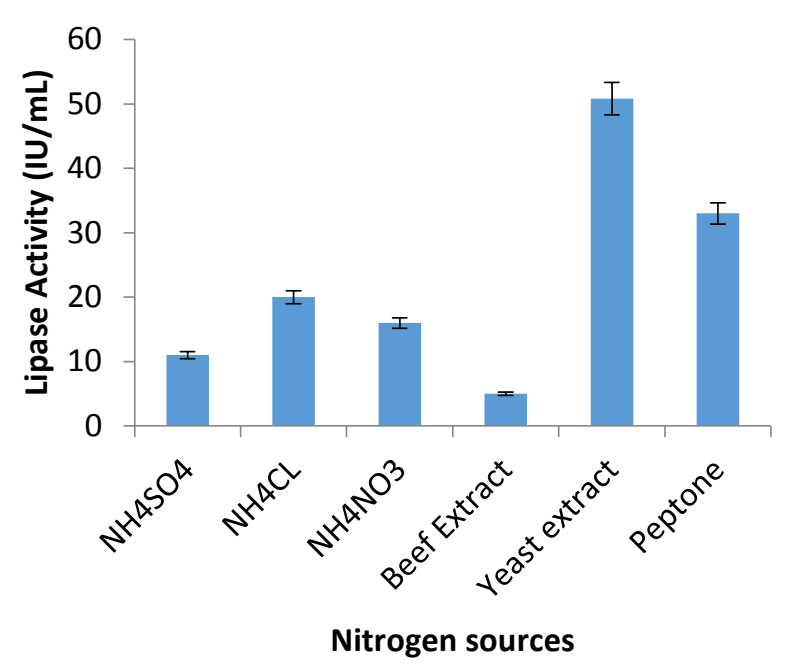

Figure 8. Effect of Nitrogen sources on production of enzymes

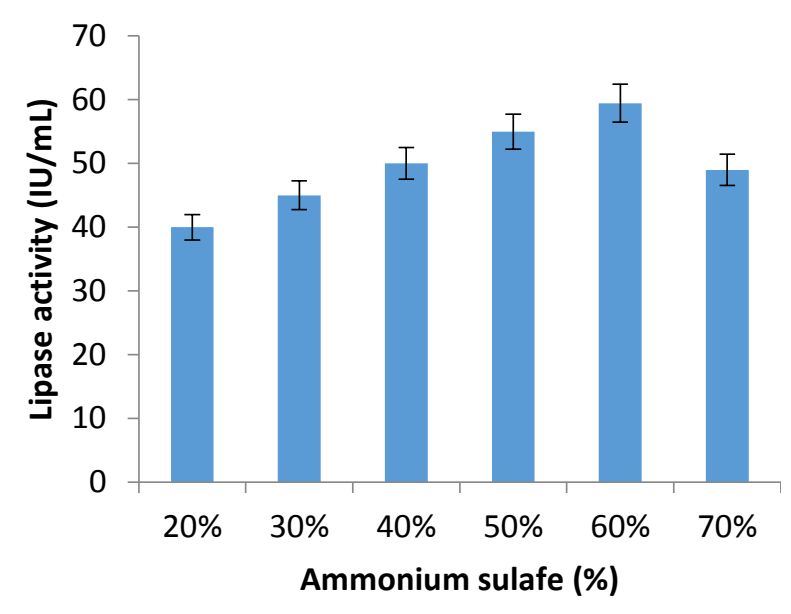

Figure 9. Purification of bacterial lipase by Ammonium Sulphate (\%age)

\section{Conclusion}

Isolated bacterial strains produce extracellular lipases with good activities. The extracellular lipase shows thermophilic nature with increasing activity during optimizing parameters. Purification procedures enhance the activities indicating the significance of techniques. The bacterial extracellular lipases could be a good candidate for various industrial applications.

\section{Authors' contributions}

Conceived and designed the experiments: MJ Asad \& RT Mahmood, Performed the experiments: MA Sultan \& S Nazir, Analyzed the data: MJ Asad \& M Mehmood, Contributed materials/ analysis/ tools: MB Shah \& S Nazir, Wrote the paper: MA Sultan \& RT Mahmood.

\section{References}

1. Reis P, Holmberg K, Watzke H, Leser ME \& Miller R (2008). Lipases at interfaces: Review. Adv. Coll Interface Sci 48: 147-148.

2. Cheetham PSJ (1995b). Principles of industrial biocatalysis and bioprocessing, In A. Wiseman (ed.) Hand Book of Enzyme Biotechnology. Ellis Horwood, UK, pp 83234.

3. Dai D \& Xia L (2005). Enhanced production of Penicillium expansum PED-03 lipase through control of culture conditions and application of the crude enzyme in kinetic resolution of racemic Allethrolone. Biotechnol Prog 21(4): 1165-8.

4. Iftikhar T \& Hussain A (2002). Effects of nutrients on the extracellular lipase 
production by mutant strain of Rhizopus oligosporous TUV31. Biotechnol 1(1): 15-20.

5. Jaeger KE \& Eggert T (2002) Lipases for Biotechnology. Curr Opinion Biotechnol 13: 390-397.

6. Fan X, Niehus X \& Sandoval G (2012). Lipases as biocatalyst for biodiesel production. In Lipases and Phospholipases, pp 471-483.

7. Khan F \& Latif Z (2016) Molecular characterization of polygalacturonase producing bacterial strains collected from different sources. J Ani Plant Sci 26(3): 612-618.

8. Ngo LT, Pham \& Le V (2008) Purification of Endopolygalacturonase from submerged culture of Aspergillus awamori L1 using a two-step procedure: Enzyme precipitation and gel filtration. Int Food Res J 15(2): 135-140.

9. Oswal N, Sharma PM, Zinjarde SS Pant A (2002) Palm oil mill effluent treatment by a tropical marine yeast. Bioresour Technol 85: 35-37.

10. Winkler VK \& Stuckmann M (1979). Thermostable lipase from Bacillus Stearothermophilus P1: Overexpression, Glycogen, hyaluronate and some other polysaccharides greatly enhance the formation of exolipase by Serratia marcescens. J Bacteriol 138:663-670.

11. Embaby AM, Masoud AA, Marey HS, Shaban NZ \& Ghonaim TM (2014) Raw agro-industrial orange peel waste as a low cost effective inducer for alkaline polygalacturonase production from Bacillus licheniformis SHG10. Springer Plus 3(1): 327.

12. Darah I, Nisha M \& Lim S (2013) Enhancement of polygalacturonase production from Enterobacter aerogenes $\mathrm{NBO} 2$ by submerged fermentation. Adv Stud 5(5): 173-189.

13. Udenwobele DI, Nsude CA, Ezugwu AL, Eze SOO, Anyawu C, Uzoegwu PN \& Chilaka FC (2014). Extraction, partial purification and characterization of pectinases isolated from Aspergillus species cultured on mango (Mangifera indica) peels. Afri $J$ Biotechnol 23(24): 2445-2454.

14. Kar S \& Ray RC (2011). Purification, characterization and application of thermostable exo-polygalacturonase from Streptomyces erumpens MTCC 7317. 35(1): 133-147

15. Pogaku P, Suresh A, Srinivas P \& Reddy SR (2010). Optimization of lipase production by Staphylococcus sp. Lp12. Afr J Biotech 9: 882-886.

16. Toida T, Ogita Y, Suzuki A, Toyoda H \& Imanari $\mathrm{T}$ (1999). Inhibition of hyaluronidase by fully O-sulfonated glycosaminoglycans. Arch Biochem Biophys 370: 176-182.

17. Sztajer H, Maliszewska I \& Wieczorek J (1988). Production of exogenous lipase by bacteria, fungi and actinomycetes. Enzyme Microbial Technol 10: 492-497.

18. Kim HK, Park SY, Lee JK \& Oh TK (1998). Gene cloning and characterization of thermostable lipase from Bacillus stearothermophilus L1. Biosci Biotechnol Biochem. 62: 66-71.

19. Motai H, Ichishima E \& Yoshida F (1966). Purification and properties of lipases from Torudopsis. Nature 210: 308-309.

20. Lee SY \& Rhee JS (1993). Production and purification of a lipase from Pseudomonas putida 35K. Enzyme Microb Technol 15: 617-623.

21. Lotti M, Monticelli S, Montesinos JL, Brocca S, Valero F \& Lafuente J (1998) Physiological control on the expression and secretion of Candida rugosalipase. Chem Phys Lipids 93: 143-148.

22. Kamini NR, Fujii T, Kurosa T \& Iefuji $\mathrm{H}$ (2000). Production, purification and characterization of an extracellular lipase from the yeast Cryptococcus sp. S-2. Process Biochem 36: 317-32. 